\title{
Young People and Political Participation: an analysis of European Union policies
}

\author{
Published in Sociological Research Online, 2008
}

\begin{abstract}
There is now widespread recognition that, far from being politically apathetic, young people across Europe are engaged in a wide range of 'political' activities. While turnout at national and European elections among the 18-25 age group may be low, researchers have highlighted diverse and creative new forms of political participation. In relation to young women, in particular, Harris (2005) has presented a compelling analysis of the new 'borderspaces' opened up between public and private domains by young women through the use of new technologies. She contends that in the face of greater surveillance and regulation brought about by the shift to neo-liberal forms of governmentality, carving out a protected space for oneself is a political act, in itself. Moreover, the creative ways in which young women across the world use such spaces - to question dominant narratives about the nature of contemporary girlhood, to resist discourses which construct young women as merely passive consumers, and to trouble conventional notions of 'youth participation' - are highly political. Some EU representatives have indicated an awareness of these new forms of engagement and professed a desire to develop links between them and more traditional forms of party politics and policy making (Hoskins, 2005). Nevertheless, the degree to which these sentiments have been translated into policy remains unclear. This article draws on recent documents on young people, citizenship and political participation to assess the extent to which these new spaces of young women's politics are, firstly, recognised and, secondly, valued within EU policy.
\end{abstract}

Keywords: political participation, young people, European Union, gender 


\section{Young People and Political Participation: an analysis of European Union policies}

\section{Introduction}

There is now widespread recognition that, far from being politically apathetic, young people across Europe are engaged in a wide range of 'political' activities. While turnout at national and European elections among the 18-25 age group may be low, researchers have highlighted diverse and creative new forms of political participation. Moreover, a number of writers (Harris, 2005; Aapola et al., 2004) have argued that some of the most innovative new forms of political engagement have been developed by young women who, in response to the restrictions of a highly regulated, neo-liberal society, have used new technologies to carve our protected political spaces for themselves. These have then been used in creative ways to question dominant discourses about young femininity and also about the 'political apathy' of the young.

Some European Union (EU) representatives have indicated an awareness of these new types of engagement and professed a desire to develop links between them and more traditional forms of party politics and policy making (Hoskins, 2005). Nevertheless, the degree to which these sentiments have been translated into policy remains unclear. This paper draws on recent EU policy documents on young people, citizenship and political participation to assess the extent to which these new spaces of young women's politics are, firstly, recognised and, secondly, valued within EU policy. First, however, to provide some context for these debates, it discusses the ways in which young women's lives have come to be understood in contemporary society. In doing so, it emphasises some similarities between the polarised nature of discourses about both girlhood and young people's political participation. 


\section{Girlhood and political engagement}

\section{Understandings of contemporary girlhood}

Recent years have witnessed the emergence of 'girl studies' as a discrete field of academic interest, offering a new and multi-disciplinary perspective on the lives of young women today (see, for example: Harris, 2004; Walkerdine et al., 2001). A central theme within this growing body of work is the contrasting, and often conflicting, ways in which girlhood is constructed in contemporary society. In their discussion of representations of the 'new' girl of the twenty-first century, Aapola and colleagues identify two key discourses. The first they term 'Girl Power'. Within this discourse the emphasis is very much on a feminist ideal: 'a new, robust, young woman with agency and a strong sense of self' (2005: 39). This, they argue, is enticing to many girls as it offers them a positive image of young femininity that stresses the wide variety of options and high degree of autonomy open to them in carving out their future. Nevertheless, while the type of girlhood constructed by this discourse is largely upbeat and optimistic, it is not without its problems. Indeed, Aapola et al. note that as a result of its 'can do' orientation, the concept of 'Girl Power' obscures the structural constraints that continue to affect young women's lives. Thus, by failing to recognise the ways in which characteristics such as gender, ethnicity, class and sexuality can still strongly influence the choices young people make, it tends to affirm neo-liberal processes of individualization.

The second discourse, which Aapola et al. term 'Reviving Ophelia', constructs a different understanding. Here, it is the vulnerability of girls and the potential dangers they face growing up that is emphasised. Aapola et al. take their name for this discourse from the 1994 publication by the American therapist and academic Mary Pipher, entitled 'Reviving Ophelia: Saving the Selves of Adolescent Girls'. They argue that this book is emblematic of a much wider belief within contemporary society that many girls have suffered a crisis of self-esteem 'as a consequence of a girl-hostile culture that denies them expression of their authentic selves in adolescence' (2005: 45). This, they contend, becomes manifest through problems such as eating disorders, depression and high-risk behaviours. In assessing the impact of this particular understanding of contemporary girlhood, Aapola et al. suggest that it 
has brought some important benefits, through its emphasis on the difficulties and barriers young women continue to face within society. Nevertheless, they go on to argue that the discourse is also deeply problematic in its individualization of social problems and the solutions it tends to promote - namely that girls need to take responsibility for themselves, for example, through seeking therapy and other forms of support, or working through their problems alone. In this way, it tends to sideline the structural causes of problems. In contrast, Aapola et al. contend that low selfesteem and many associated issues are a result of the ways in which young women internalise (and individualize) the structural inequalities that continue to characterise late modern society, and which they encounter 'because they are female in a world that was never designed for women' (2005: 55). They go on to conclude that while the 'Girl Power' and 'Reviving Ophelia' discourses of contemporary girlhood may appear contradictory, they are both grounded within an individualized understanding of society in which young women's subjectivities are seen as projects that can be shaped by the individual (2005: 54).

\section{Young people's political engagement}

These conflicting discourses about the nature of contemporary girlhood are reflected to some extent in similarly polarised debates about young people's political engagement, played out through the media, policy documents and academic texts. Loader (2007) distinguishes between a pessimistic 'disaffected citizen' perspective and a more upbeat 'cultural displacement' discourse. The former emphasises young people's mistrust of politicians, disenchantment with political institutions, political apathy and more general disengagement from the public sphere, and suggests that these trends are likely to lead to the weakening of democratic citizenship. In contrast, the cultural displacement perspective is predicated upon the assumption that 'young people are not necessarily any less interested in politics than previous generations but rather that traditional political activity no longer appears appropriate to address the concerns associated with contemporary youth culture' (2007: 1-2). In this analysis, collective forms of political action are seen to have been replaced by more fluid and individualized forms of engagement and expression. This binary has much in common with Bennett's (2007) comparison between 'dutiful citizens' and their 'selfactualising' counterparts. 'Dutiful citizens' are, in his typology, those associated with 
traditional politics: they typically join civil society organisations and/or political parties, believe that voting is the core democratic act and feel an obligation to participate in government activities. However, it is the 'actualising citizen' who, Bennett argues, better represents many young people today: he or she is motivated by a sense of individual purpose rather than obligation to government, perceives voting as less meaningful than other political acts, and favours loose networks of community action (often facilitated by new technologies).

In assessing the extent to which these ideal types map onto the available empirical data about young people's political activities, there is certainly strong and welldocumented evidence that young people are not as engaged as other age groups with formal politics - at least as measured through participation in national elections (Buckingham, 2000; Adsett, 2003). In his analysis of voting in the UK's general election in 2005, for example, Phelps (2005) shows how reported turnout amongst the 18-24 age group was 44.3 per cent, compared with 71.3 per cent for the 35-44 age group and 86.1 per cent amongst those aged 65 or more. It is also clear from Phelps' data that turnout has fallen significantly amongst this age group over recent decades. Indeed, the figure for 2005 (44.3 per cent) can be contrasted with the 75.4 per cent reported turnout for the same age group in 1992 and the 88.6 per cent reported in 1964. While some of this decline can be attributed to a 'period effect' (i.e. something that depressed turnout among all age groups between 1992-2001), it is possible that we may also be seeing a generational shift. Indeed, Phelps argues that those young people in the 18-24 age group in 2005 have been subject to a unique array of political influences, many of which have been negative. These include growing up in a highly individualized and marketised society in which not voting is less likely to be seen as a serious neglect of civic duty, and coming of voting age 'in a period characterised by weak leadership, policy incompetence, sleaze and scandal' (2005: 486).

To test some of these and other speculative hypotheses about the reasons for young people's apparent disengagement with formal politics, Henn et al. (2005) conducted a nationwide survey of more than 700 'attainers' - young people eligible to vote in an election for the first time. Their data suggest that young people do profess an interest in formal politics, and are committed to the idea of elections and the democratic process more generally. Nevertheless, respondents indicated that they had been 
alienated from formal politics, as presently practised in the UK, by their perception that they had little or no influence on political affairs as well as their negative view of political parties and professional politicians. Henn and colleagues conclude that evidence such as this 'indicates that young people in Britain are sufficiently interested in political affairs to dispel the myth that their apparent disconnection from formal politics is as a consequence of their general apathy' (2005: 573). While Henn et al. demonstrate convincingly that young people's disinclination to vote is not explained well by claims of apathy, they do nevertheless employ a rather narrow definition of politics (focussing largely on the formal and institutional), which sheds little light on how young people themselves understand the term.

O'Toole et al. (2003) suggests that, in relation to young people in particular, it can be helpful to adopt a bottom-up approach, one which does not impose definitions of what is or is not political upon respondents but, instead, engages with their own understandings. Moreover, they also argue that it is erroneous to see apathy and participation as a simple dichotomy. Indeed, they contend that non-participation in formal politics can itself be a conscious choice, and thus a means of political engagement. Research that has employed broader understandings of 'the political' has typically found evidence of much higher levels of engagement amongst young people. Indeed, studies of voluntary activity conducted by young men and women has emphasised its political nature (Roker et al, 1999; Brooks, 2007). Furthermore, Vromen's research on the 'participatory citizenship' of young Australians highlighted the high degree of political engagement evident among her respondents. She notes that while a large majority of the 18-34 year-olds in her study had taken part in the most individualized and least institutionalised of the 'participatory acts' they were asked about (such as donating, volunteering and boycotting), 'as acts became more institutionalised (contacting officials) or more collectively oriented (rallies), the proportion of the sample who have ever participated in these acts drops to less than a quarter' (2003: 85). Moreover, Lash and Urry (1994) have suggested that far from being apathetic, young people are at the forefront of developing new social movements and global forms of activism - facilitated in large part by new forms of technology. 
Gender has tended to be overlooked in many analyses of young people's political participation. Indeed, Aapola et al. maintain that 'unquestioned assumptions about youth apathy are often redoubled in the case of young women' (2005: 188). Nevertheless, some of the more recent studies that have employed a broader conceptualisation of political engagement have paid greater attention to gender as well as various other social characteristics. Vromen (2003) argues that, amongst her respondents, young women were more likely than their male counterparts to take part in activities that she labels 'activist' (such as attending a rally or march, boycotting products and joining campaigning organisations) and/or 'communitarian' (for example, volunteering, joining a youth club or church group and contacting an MP). They also had a significantly higher average number of total 'participatory acts' than men. In their research with a younger age group (14 year-olds) in America, Hooghe and Stolle (2004) found high levels of anticipated political participation - with girls mentioning more political activities in which they intended to engage than boys. Again, there were some differences in the type of anticipated activity, with girls more inclined than boys to favour social movement-related activities and less likely to be attracted to more radical and confrontational forms of political engagement.

While several writers have commented upon the potential for new technologies to open up new forms of political engagement amongst the young (Bennett, 2007; Livingstone et al., 2005), Harris has presented a compelling analysis of the innovative ways in which many young women are already exploiting such media. In particular, she highlights the new 'borderspaces' opened up between public and private domains by young women through the use of the internet and other new technologies. For example, the internet offers a space for young women to talk without having to disclose their name, address or other personal details. This, she claims, is a state of 'simultaneous presence and absence' which 'works well for young women seeking to combine a desire to organise and communicate with others with a need to avoid surveillance and appropriation of their cultures and politics' (2004: 161). It thus allows them 'greater potential for political efficacy than is achieved in a purely public space, but with less risk than is afforded by more traditional and regulated public sites' (ibid.). These borderspaces offer young women safe spaces to discuss sensitive 
topics (such as same-sex attraction) and to create narratives that bring into question dominant representations of young women. More specifically, it is claimed that such spaces:

Foster girls' public self-expression, often understood as the ability to tell private stories (secrets) which are otherwise prohibited or repressed by the dominant culture..... Thus publicised, such narratives often become the stuff of political commitment and an affirmation of girls' legitimacy within the realm of the political. (Gottlieb and Wald quoted in Harris, 2004:164)

Harris (2004) contends that in the face of greater surveillance and regulation of young people - and young women, in particular - brought about by the shift to neo-liberal forms of governmentality, carving out a protected space for oneself is a political act, in itself. Furthermore, the creative ways in which young women across the world use such spaces - to question dominant narratives about the nature of contemporary girlhood, to resist discourses which construct young women as merely passive consumers, and to trouble conventional notions of 'youth participation' - are highly political. Thus, these more recent studies of the extent and nature of young people's political engagement have provided strong evidence that young women are both interested in political issues and willing to take action for political ends - even if this is not always recognised by politicians, policymakers and social commentators. As such, they provide an important contrast to some studies of older adults, which have suggested that women are less interested in politics than men, and participate less in political life (Atkeson and Rapoport, 2003; Carroll, 2003). They also highlight the contribution of young women, in particular, to the development of innovative new ways of political expression, and thus offer little support for the 'disaffected citizen' perspective.

\section{Young people and the European Union}

The concern about alleged political apathy and young people's apparent reluctance to participate in formal politics is not unique to the UK. Researchers in Australia, Canada and many parts of Europe have pointed to similar trends (Bessant, 2004; Kloep and Hendry, 1997). There are, however, some national differences in the 
theses put forward to explain these patterns. For example, in relation to eastern Germany, in particular, Oswald and Schmid (1998) have argued that the disengagement with formal politics evident amongst young people can be linked to their wider disillusionment with democracy as a result of their experiences since reunification. In contrast, in Norway, the decline in youth employment during the 1990s has been argued by some to account for an increasing disinterest in formal politics (Carle, 2000).

Nevertheless, if one adopts a broader conceptualisation of politics and political engagement, as discussed above, then a different picture emerges (Pleyers, 2005). For example, in Germany, Nolan has shown how various youth subcultures - including the rave scene - work politically 'against the mechanisms of ...[formal] civil power that would define and control youth culture' (2001: 309). Moreover, the Young Europeans Survey (Flash Eurobarometer, 2007) highlights interesting differences across the continent in the types of political activity pursued by young people. For example, while voting in elections was highest in Belgium (where it is compulsory), Sweden and Italy and lowest in Latvia, the UK and Portugal, taking part in demonstrations was most common in southern Europe and Germany, while trade union membership was more prevalent amongst the young people of Scandinavia, the UK, Ireland and the Netherlands.

The literature suggests that there may be comparable differences in the extent to which young people across Europe have taken on a distinctly 'European' political identity. Lutz et al.'s (2006) analysis of Eurobarometer data suggests that young Europeans are more likely than older groups to consider themselves to have a European identity alongside their national one. For example, in 2004, almost 70 per cent of the 20-24 age group claimed to have a 'multiple' political identity, compared to only just over 50 per cent of those between the age of 75-79. They argue that their analysis points to a definite cohort effect, and suggests that current younger generations within Europe have been socialised in such a way that they are likely to maintain their multiple identities throughout their lives. Indeed, they predict that by 2030, within the 33-40 age group, those who identify as European in some way will outnumber those who do not by three to one. However, Lutz et al.'s work also highlights significant variation between countries in the prevalence of reported 
'multiple identities'. For example, according to their data, between 1996 and 2004, an average of 78 per cent of respondents from Luxembourg reported multiple identities, compared with 54 per cent of Danish respondents and only 40 per cent of those from the UK. Qualitative research has tended to point to similar disparities. In comparing the attitudes towards and knowledge of Europe held by young people in Germany and the UK, Faas (2007) contends that the considerable differences he found can be explained by differences in the wider political climate of the two nations, and the extent to which European issues are included within the school curriculum. In contrast, Grundy and Jamieson (2007) suggest that education (the curriculum itself and the degree to which foreign languages are promoted and/or taken up) has a relatively small part to play in explaining national differences. Instead, they argue that it is the extent to which young people are provided with opportunities to develop friendships and share meaningful experiences with other EU nationals that is key. Their comparative analysis also presents a more complex understanding of European political identity than that offered by the Eurobarometer data discussed by Lutz et al. While they point to the growth in identification with Europe, they also argue that most young people across Europe have stronger feelings for their local region and/or their nation than they have for Europe. They also sound a note of caution in how commitment to a European political identity should be understood:

Those who identify themselves as European were not necessarily more tolerant of cultural, national and ethnic diversity. It clearly cannot be assumed that fostering European identity will necessarily also foster a tolerant, caring Europe, and not a racist or chauvinistic 'fortress' Europe. (Jamieson and Grundy, 2005: 131)

As many analyses of EU policy over decades has shown, young people have often been a central focus of measures to inculcate a European identity. These have included various educational initiatives, such as the ERASMUS scheme, founded in 1987, to encourage university students to spend a year of their studies at an institution in another European country (see, for example, King and Ruiz-Gelices, 2003). Recent EU youth policies have also put forward a range of measures to promote a European identity - alongside other initiatives that focus on young people's political 
engagement more generally. These are now considered in more detail and provide the focus for the following sections of this paper.

\section{EU policy and young people's political engagement}

To date it is unclear how EU policies that hope to promote political participation and active citizenship articulate with the new forms of engagement - predicated upon broader conceptualisation of politics - that have been documented within the academic literature and discussed above. Some EU officials have certainly suggested that more needs to be done to engage with the types of non-formal politics favoured by the young (Hoskins, 2005) but it cannot be assumed that these intentions have automatically been translated into practice. The article now considers a number of recent publications from the European Union on youth to explore the extent to which EU policymakers have attempted to engage with the new forms of political engagement favoured by, for example, the 'actualising citizen' and young women who are carving out 'borderspaces' for themselves (see Annex 1 for further details). All address youth policy, in a broad sense, but most include a specific focus on measures to further the political participation of young people and/or develop their identity as a 'citizen'. These are:

- $\quad$ 'A New Impetus for European Youth' (CEC, 2001), published in 2001. This White Paper, written by the European Commission and drawing on a largescale consultation across Europe, offers strong encouragement to young people to become involved in public life, and in the design and implementation of public policies. It also urges member states to co-operate in the framing of their youth policies.

- Resolutions of the Council of Ministers (in 2002 and 2005), which followed the 2001 White Paper. They established a 'Framework for European Cooperation in the Field of Youth' (EC, 2002). This comprises three main strands, one of which is the promotion of 'active citizenship' among young people, through the Open Method of Co-ordination (OMC) ${ }^{\mathrm{i}}$. 
- The 'European Youth Pact' (EC, 2005), published by the European Council in 2005 as part of the revised Lisbon Strategy. This aims to improve the education, training and social inclusion of young people, while reconciling family and working life.

- $\quad$ The 'Youth in Action Programme 2007-2013' (EC, 2006), published in 2006. One of the central aims of this programme is to heighten young people's awareness that they are European citizens, and to encourage them to participate more fully in discussions about the future of the European project.

These documents were analysed thematically - in terms of: the ways in which 'young people' are understood; the recognition given to current forms of political participation amongst the young; the policies proposed for engaging young people more fully; and the extent to which gender is addressed. The remainder of this paper considers some of the key themes that emerge from analysis of these five documents in light of some of the claims within the academic literature discussed in the earlier part of the article.

\section{$i$. The notable absence of gender}

As noted above, the White Paper, 'A New Impetus for European Youth', drew on a large-scale consultation exercise with young people across Europe, and the annex to this document presents a summary of their views on relevant topics. This states clearly that many of the young people who were consulted believed that gender issues needed more attention within EU policy (2001: 49). Nevertheless, it is notable that, with the exception of a discussion of measures to reconcile family and work commitments and of workplace discrimination, gender is absent from all five policy documents. It is briefly mentioned as one of many variables that can lead to the polarisation of opportunities for young people (2001: 47), but this analysis is not developed in any sustained manner, and no consideration is given to ways in which 'difference' in gender (or indeed in relation to other social characteristics) may be addressed by policy. 
This reluctance to engage with the differences between young men and young women's lives overlooks the large body of research that has documented the various ways in which gender continues to have a significant impact on the life chances, opportunities and experiences of young people across Europe (e.g. Brannen and Nilsen, 2002; du Bois Reymond, 1998). Furthermore, many of the specific policy recommendations advanced by the various documents fail to engage with some of the gender-related issues raised by the academic literature. For example, the White Paper tells us that:

It is on the ground, where young people can see the results of their personal commitment, that active citizenship becomes a reality....It is by throwing themselves into social activities which are open to all, without any form of discrimination, that young people can make their contribution to a more solidarity-conscious society and live citizenship to the full. (2001: 5)

It seems naive, at the very least, to assume that all social activities are open to young people 'without any form of discrimination'. As discussed above, recent research has outlined significant differences by gender in the ways in which young men and young women engage with the political, and the types of issues they pursue. Moreover, studies from the UK have also shown how young men tend to dominate activities that are deemed (by some teachers and young people at least) to be more 'prestigious' and influential such as school and youth councils and students unions (Brooks, 2006; Roker et al., 1999). Indeed, in their analysis of the models of citizenship that underpin much youth work in the UK, Hall and Coffey argue that while none of the activities with which the young people were engaged were inevitably gendered,

In practice the distinctions were clearly demarcated. Some of this segregation was intended, the result of an explicitly gendered organisation of space and activity on the part of youth work staff looking to make room for emergent, gendered identities and groupings. More often, however, space occupied and activities engaged in 'just ended up', and not altogether unsurprisingly, structured in this way. (2007: 287) 
They thus conclude that while such settings aim to make open and democratic space for young people, 'they remain pronouncedly gendered settings, in ways that necessarily cross-cut the citizenship agenda' (ibid.)

\section{ii. Deficit model assumed}

As discussed earlier in this paper, recent scholarship on young people and political engagement has tended to emphasise the important ways in which they are politically active, even if this is not in relation to formal politics or conducted through conventional means of participation. The White Paper does, in places, acknowledge this reframing of the debate, and recognise the new ways in which young men and women are engaging with the political: for example, it reports that many young people 'regard the view that they are disinterested or uncommitted as groundless and unjust' (2001: 24), suggesting that policymakers may be sympathetic to the cultural displacement discourse outlined by Loader. However, this analysis is not consistent throughout the document. Indeed, in many places a very different understanding is proffered, and a deficit model is often assumed. For example, it argues that if the European project is to progress, it needs 'commitment on the part of young people to the values on which it is based' (2001: 7), implying that, at present, such commitment is lacking. Similarly, in the Youth in Action document, the programme's aim to 'inspire a sense of European citizenship among the youth of Europe' appears to be underpinned by a clear assumption that they currently lack this citizenship.

This view is also implicit in the suggestion put forward within a number of these documents that, in order to address problems with political participation, it is young people who have to change, rather than institutions:

Despite the more complex social and economic context, young people are well-equipped to adapt. It is up to the national and European policy-makers to facilitate this process of change by making young people stakeholders in our societies. (2001: 4, italics added)

Emphasis is thus placed on the importance of young people learning how to participate, rather than recognising the ways in which they are doing so already. The 
Youth in Action programme, for example, has four priorities, one of which focuses on the 'participation of young people'. This is itself comprised of three dimensions: to increase the participation by young people in the civic life of their community; to increase participation by young people in the system of representative democracy; and greater support for various forms of learning to participate (EC, 2006: 7; italics added). This resonates with broader debates within youth studies literature that have emphasised the construction of adolescence as a period of "always "becoming", waiting for the future to arrive' (Lesko, 2001: 111). Lesko argues that this tends to promote a passivity on the part of young people as they are told that it is only the future that matters.

When we consider the way in which young femininity is understood across the range of documents, it is clear that a gender focus is notably absent (a point which has already been made above). Nevertheless, the construction of youth, more generally, has much in common with the 'Reviving Ophelia' discourse discussed previously, as the following extracts indicate:

All this [the changing nature of youth including, for example, more protracted transitions to adulthood] is often reflected in a sense of fragility, a loss of confidence in the existing decision-making systems, and a degree of disaffection in terms of the traditional forms of participation. (CEC, 2001: 4)

Young people have a sense of uncertainty and of the difficulties that they will encounter in their private and professional lives... an awareness of the fragility of their own situation. (CEC, 2001:14)

This pessimistic view of contemporary youth articulates with the deficit model of political engagement outlined above to problematise both the outlook and actions of young men and women across Europe, paying little attention to the more positive accounts of participation emphasised within much of the academic literature and in the narratives of many young people themselves. 


\section{iii. Narrow conceptualisation of citizenship and political participation}

In their longitudinal study of young British people's understandings of citizenship, Lister et al. (2005) argue that over the period in which they collected data (from 1999 until 2001) they witnessed a shift away from conceptualisations that emphasised the rights of citizens towards, what they term, 'constructive social participation'. They contend that, in many ways, this mirrors the wider political discourse in the UK over the same period, which has prioritised responsibilities over rights, and emphasised the centrality of social cohesion and civic renewal to notions of citizenship. The five youth-related policy documents provide evidence of a similar discourse operating at the European level. Indeed, social cohesion is frequently emphasised and linked in a direct and explicit manner to understandings of citizenship and political participation. In the White Paper, for example, it is argued that by 'throwing themselves into social activities' in schools and other arenas, young people can 'live citizenship to the full' (2001: 5). Similarly, one of the four priority themes of the 2002 Resolution encourages:

...young people's participation in the exercise of active citizenship and civil society. This means supporting the work of youth associations and other forms of active participation in order to improve young people's participation and social cohesion.

Moreover, as part of this wider discourse of citizenship as 'constructive social engagement', particular emphasis is placed on voluntary work. This is argued to be an important means of fostering active citizenship and political participation amongst young people. A second theme of the 2002 Resolution is to promote voluntary activities among young people. This involves 'making it easier for young people to find voluntary work so as to develop their sense of responsibility and citizenship and their active participation in society.' This emphasis on belonging, conformity and duty to others, in contrast to more radical understandings of citizenship, is evident in the conceptualisation of volunteering as a form of service, here outlined clearly in the White Paper: 
Voluntary service is a form of social participation...and a factor in employability and integration....efforts should be made in years to come to develop voluntary service significantly at national, regional and local levels. (2001: 17)

While volunteering can often further social cohesion and encourage young people to participate more fully in their communities, it does tend to entrench a particular understanding of political engagement that may not articulate well with the new forms of participation outlined in the first part of this paper. Indeed, Garmanikow and Green (2000) have argued that an emphasis on active citizenship, volunteering and community involvement may well undermine a more rights-based understanding of citizenship. Thus, in their emphasis on social cohesion, these policies give relatively little recognition to the more oppositional forms of political engagement which have been documented within the academic literature. Where such forms are recognised, they are generally problematised. For example, the White Paper notes that: 'Some young people have taken refuge in indifference or individualism, while others have tried forms of expression which may have been excessive or even on the margins of democratic means' (2001: 4).

Alongside this privileging of 'constructive social engagement' within EU policies, young people's commitment to the European project often seems to be misrepresented. For example, despite evidence of some young people's antipathy to a European identity cited above, the White Paper claims that:

Mindful that decisions are increasingly being taken at European level, young people want to become involved in Europe. They want a new European youth initiative and greater co-ordination of national youth policies.... (2001: 55)

Moreover, all five documents tend to overlook the high level of contestation about the nature of 'European citizenship', treating it as a largely unproblematic term. The Youth in Action programme, for example, 'aims to inspire a sense of European citizenship among the youth of Europe' on the basis that is something they are currently lacking. 
A long-standing critique of EU policy is its promotion of a narrow and economicallydriven understanding of citizenship. Indeed, Weller (2007) argues that, as a result of this focus, EU conceptualisations of citizenship and political participation have tended to exclude young people under the age of eighteen - as the dominant Western understandings of childhood deny children access to full-time work. It is unfair to claim that the various youth documents discussed here are focussed solely (or even mainly) on the economic: social cohesion and political identity, for example, are both important and structuring themes. Nevertheless, it is notable that the social integration of young people appears to be understood largely in relation to the labour market, rather than civil or political society. The White Paper, for example, argues that 'employment is a prerequisite for social inclusion', going on to contend that 'to have a job means adult status, self-respect, money, independence...' (2001: 38). This theme within the five youth documents has much in common with the findings of the UK study conducted by Lister and colleagues (2005), discussed above. They found that, over the course of their research, increasing numbers of young people came to understand citizenship as 'respectable economic independence'. This, they argue, is inextricably bound up with wider political discourses about citizenship and political participation and, in particular, the centrality of paid work to New Labour's concept of the socially and politically integrated citizen (see also Levitas, 2000).

It is also notable that while individualism and autonomy are welcomed in relation to employment within the EU policies (there is, for example, considerable space within the White Paper devoted to methods of promoting entrepreneurship amongst young people), they are problematised with respect to political participation. Indeed, instead of welcoming some of the new and more individually-oriented forms of political engagement discussed above, the White Paper laments that some young people have eschewed collective action and are instead seeking 'refuge in indifference or individualism' (2001:4). Moreover, individual forms of participation seem to be considered of lesser value when compared to more traditional methods of engagement. 
The discussion of individualized forms of political participation is not, however, always consistent. Indeed, the White Paper and the other policy documents do, in places, engage with the individualized, 'self-actualising' citizen outlined by Bennett (2007) and others. For example, it is recognised that some young people may wish to participate 'on a more individual and more one-off basis, outside of the old participatory structures and mechanisms', and that 'it is up to the public authorities to bridge the gap between young people's eagerness to express their opinions and the methods and structures which society offers' (2001: 10). Nevertheless, frequently this interpretation is sidelined in favour of measures to develop 'dutiful citizens' (Bennett, 2007) who participate in more conventional ways, through more traditional channels such as youth councils, which are strongly promoted in several of the policy documents. The White Paper, for example, argues that 'The majority [of young people]...want to influence policies, but have not found the appropriate way of doing so' (2001: 4), while the 2002 Resolution contends that furthering young people's participation requires 'supporting the work of youth associations and other forms of active participation in order to improve young people's participation..' (italics added). Thus, within this analysis, new methods of participation are clearly problematised.

\section{Conclusion}

The discussion above has explored the various ways in which the political participation and citizenship of young people has been understood within recent EU policy documents. It has highlighted a number of ways in which policy discourses articulate with Loader's more optimistic 'cultural displacement' perspective and make passing reference to the emergence of what Bennett has termed the 'actualizing citizen' of contemporary society. Nevertheless, as a result of their tendency to problematise young people's political engagement and construct them as citizens-inthe-making, in need of educational programmes and socialisation into more traditional forms of participation, it is the 'disaffected citizen' discourse that is privileged. Moreover, as a result of the emphasis on the responsibilities of young people rather than their rights, the policy documents tend to reinforce a narrow definition of 
citizenship, and give little recognition to the more oppositional ways in which some young people are choosing to engage with local, national, regional and global politics. These patterns are, of course, not unique to the EU. Indeed, within the UK various writers have pointed to the tensions within citizenship education programmes which, on one hand purport to encourage an active citizenship committed to, for example, changing unjust laws and, on the other, put forward a controlling agenda, aiming to socialise young people into particular social norms (Coffey, 2004; Cunningham and Lavalette, 2004).

The analysis above has also suggested that gender is notably absent from all five policy documents. As such, they fail to recognise differences by gender in the ways in which young people are engaging with the political, and also the continuing impact of gender on the life experiences of young men and women across Europe. Perhaps most significantly, the gender-blind 'disaffected citizen' which is privileged in these accounts fails to engage with the creative ways in which young women are attempting to forge a new type of politics, and claiming new spaces in which to affirm a political identity.

\section{Annex 1: Details about documents analysed}

\begin{tabular}{|c|c|c|c|}
\hline Text & Authors & Status & Structure/content \\
\hline $\begin{array}{l}\text { A New Impetus for } \\
\text { European Youth (CEC, } \\
2001)\end{array}$ & European Commission & $\begin{array}{l}\text { White Paper - contains an } \\
\text { official set of proposals in the } \\
\text { area of youth policy, to be } \\
\text { used as a vehicle for their } \\
\text { development. Addressed to } \\
\text { EU Member States. }\end{array}$ & $\begin{array}{l}\text { Comprised of the following } \\
\text { sections: Background; } \\
\text { Challenges; Consultation } \\
\text { Exercise; A New Ambition; } \\
\text { Conclusion. }\end{array}$ \\
\hline $\begin{array}{l}\text { Resolution of the Council of } \\
\text { Ministers (2002) }\end{array}$ & Council of Ministers & $\begin{array}{l}\text { Official adoption of the } \\
\text { White Paper 'A New Impetus } \\
\text { for European Youth' by } \\
\text { representatives of the } \\
\text { governments of the Member } \\
\text { States. Addressed to EU } \\
\text { Member States. }\end{array}$ & $\begin{array}{l}\text { Set priorities and timetable for } \\
\text { EU's work until } 2004 \text { in the } \\
\text { field of 'youth'. Includes the } \\
\text { following: co-operation based } \\
\text { on the Open Method of Co- } \\
\text { ordination; taking greater } \\
\text { account of 'youth' dimension } \\
\text { in other policies; updated } \\
\text { framework for co-operation; } \\
\text { promoting active citizenship } \\
\text { among young people }\end{array}$ \\
\hline $\begin{array}{l}\text { Resolution of the Council of } \\
\text { Ministers (2005) }\end{array}$ & Council of Ministers & $\begin{array}{l}\text { Official updating of the } 2002 \\
\text { Resolution by representatives } \\
\text { of the governments of the } \\
\text { Member States. Addressed to } \\
\text { EU Member States. }\end{array}$ & Updated 2002 Resolution. \\
\hline European Youth Pact (2005) & European Council & $\begin{array}{l}\text { Annex of Presidency } \\
\text { Conclusions of the European } \\
\text { Council. Integrated part of } \\
\text { the Lisbon Strategy. } \\
\text { Addressed to EU Member } \\
\text { States. }\end{array}$ & $\begin{array}{l}\text { Calls on EU and Members } \\
\text { States to take action in the } \\
\text { following areas: employment, } \\
\text { integration and social } \\
\text { advancement; education, } \\
\text { training and mobility; }\end{array}$ \\
\hline
\end{tabular}


reconciliation of working life and family life.

Youth in Action Programme European Commission (2006)

Puts into effect the legal framework to support nonformal learning activities for young people. Contributes to fulfilment of aims set out in the Lisbon Strategy and the European Youth Pact, amongst others.

Addressed to EU Member States.
Comprised of 5 distinct

'Actions': Action 1 - Youth for Europe; Action 2 -

European Voluntary Service; Action 3 - Youth in the World; Action 4 - Youth Support Systems; Action 5 - Support for European C-operation in the Youth Field.

\section{References}

AAPOLA, S., GONICK, M. and HARRIS, A. (2005) Young Femininity. Girlhood, Power and Social Change Basingstoke, Palgrave.

ADSETT, M. (2003) Change in Political Era and Demographic Weight as

Explanations of Youth 'Disenfranchisement' in Federal Elections in Canada, 19652000, Journal of Youth Studies, 6, 3, 247-264.

ATKESON, L. and RAPOPORT, R. (2003) The more things change the more they stay the same: examining gender differences in political attitude expression 19522000, Public Opinion Quarterly, 67, 4, 495-521.

BENNETT, L. (2007) Civic Learning in Changing Democracies: Challenges for Citizenship and Civic Education, in: DAHLGREN, P. (ed) Young Citizens and New Media London, Routledge.

BESSANT, J. (2004) Mixed messages: youth participation and democratic practice, Australian Journal of Political Science, 39, 2, 387-404.

du BOIS REYMOND, M. (1998) 'I don't want to commit myself yet': young people's life concepts, Journal of Youth Studies, 1 (1). pp. 63-79. 
BROOKS, R. (2006) Young people and active citizenship: a gender analysis. Paper presented to ESRC seminar series on 'Gender, Participation and Citizenship' UWE, 28 June 2006.

BROOKS, R. (2007) Young people's extra-curricular activities: critical social engagement - or 'something for the CV'?, Journal of Social Policy 36, 3, 417-434.

BUCKINGHAM, D. (2000) The Making of Citizens. Young People, News and Politics London, Routledge.

CARLE, J. (2000) Political activity in the context of youth unemployment.

Experiences from young people in six Northern European countries' Young 8, 4.

CARROLL, S. (ed) (2003) Women and American Politics. New Questions. New Directions Oxford, Oxford University Press.

COMMISSION OF THE EUROPEAN COMMUNITIES (CEC) (2001) A New Impetus for European Youth (European Commission White Paper) Available at: http://eur-lex.europa.eu/LexUriServ/site/en/com/2001/com2001_0681en01.pdf (Accessed 12/2/08).

CUNNINGHAM, S. and LAVALETTE, M. (2004) 'Active citizens' or 'irresponsible truants'? School student strikes against the war, Critical Social Policy, 24, 2, 255-269.

EUROPEAN COMMISSION (EC) (2006) Youth in Action 2007-2013. Programme Guide Available at: http://ec.europa.eu/youth/index_en.html (Accessed 6/6/07).

EUROPEAN COUNCIL (EC) (2002) Framework of European Co-operation in the Youth Field Available at: http://europa.eu/scadplus/leg/en/cha/c11059.htm (Accessed $12 / 2 / 08)$

EUROPEAN COUNCIL (EC) (2005) European Youth Pact (Annex 1 of Presidency Conclusions of the European Council, March 2005) European Council. 
FAAS, D. (2007) Youth, Europe and the Nation: the political knowledge, interests and identities of the new generation of European youth, Journal of Youth Studies, 10, 2, 161-181.

FLASH EUROBAROMETER (2007) Young Europeans. Survey among young people aged 15-30 in the European Union. Available at:

http://ec.europa.eu/public_opinion/flash/fl_202_sum_en.pdf (Accessed 25/1/08).

GAMARNIKOW, E. and GREEN, A. (2000) Citizenship, education and social capital. In: LAWTON, D., CAIRNS, J. and GARDNER, R. (eds) Education for Citizenship London, Continuum.

GRUNDY, S. and JAMIESON, L. (2007) European Identities: from absent-minded citizens to passionate Europeans, Sociology, 41, 4, 663-680.

HARRIS, A. (ed) (2004) All About the Girl. Culture, Power and Identity New York, Routledge.

HARRIS, A. (2004) Future Girl. Young Women in the Twenty-First Century New York, Routledge.

HENN, M., WEINSTEIN, M. and FORREST, S. (2005) Uninterested Youth? Young People's Attitudes Towards Party Politics in Britain, Political Studies, 53, 556-578.

HOSKINS, B. (2005) Translating research results into policy, in: FORBRIG, J. (ed) Revisiting Youth Political Participation Council of Europe.

JAMIESON, L. and GRUNDY, S. (2005) Political Participation and European Citizenship Identity, in: FORBRIG, J. (ed) Revisiting Youth Political Participation Council of Europe.

KING, R. and RUIZ-GELICES, E. (2003) International Student Migration and the European 'Year Abroad': effects on European identity and subsequent migration behaviour, International Journal of Population Geography, 9, 229-252. 
KLOEP, M. and HENDRY, L. (1997) In three years we'll be just like Sweden! Anomie, Albania and university students, Young 5, 4.

LASH, S. and URRY, J. (1994) Economies of Signs and Space London, Thousand Oaks.

LESKO, N. (2001) Act Your Age! A Cultural Construction of Adolescence New York, RoutledgeFalmer.

LEVITAS, R. (2000) What is social exclusion? In: GORDON, D. and TOWNSEND, P. (eds) Breadline Europe Bristol, Policy Press.

LISTER, R., SMITH, N., MIDDLETON, S. and COX, L. (2003) Young people talk about citizenship: empirical perspectives on theoretical and political debates, Citizenship Studies, 7, 2, 235-253.

LIVINGSTONE, S., BOBER, M., HELSPER, E. (2005) Active participation or just more information? Young people's take-up of opportunities to act and interact on the internet, Information, Communication and Society. 2005; 8(3): 287-314

LOADER, B. (ed) (2007) Young Citizens in the Digital Age. Political Engagement, Young People and New Media London, Routledge.

LUTZ, W., KRITZINGER, S. and SKIRBEKK, V. (2006) The Demography of Growing European Identity, Science, v.314, p.425.

NOLAN, M. (2001) 'Opposition Machen Wir!' Youth and the contestation of civic and political legitimacy in Germany, Childhood, 8, 2, 295-314.

O’TOOLE, T., LISTER, M., MARSH, D., JONES, S. and McDONAGH, A. (2003)

Tuning out or left out? Participation and non-participation among young people, Contemporary Politics, 9, 1, 45-61. 
OSWALD, H. and SCHMID, C. (1998) Political participation of young people in East Germany, German Politics, 7, 3, 147-164.

PHELPS, E. (2005), Young Voters at the 2005 British General Election, The Political Quarterly, 76:4, 482-487.

PLEYERS, G. (2005) Young people and alter-globalisation: from disillusionment to a new culture of political participation, in: FORBRIG, J. (ed) Revisiting Youth Political Participation Council of Europe.

ROKER, D., PLAYER, K. and COLEMAN, J. (1999) Young people's voluntary and campaigning activities as sources of political education, Oxford Review of Education, $25,1,185-198$.

VROMEN, A. (2003) 'People Try to Put Us Down...': Participatory citizenship of 'Generation X', Australian Journal of Political Science, 38, 1, 79-99.

WALKERDINE, V., LUCEY, H. and MELODY, J. (2001) Growing Up Girl: psychosocial explorations of gender and class Basingstoke, Palgrave.

WELLER, S. (2007) Citizenship for Teenagers, London, Routledge.

\footnotetext{
${ }^{\mathrm{i}}$ The OMC 'allows member states to co-operate through sharing best practice on participation by young people, information for young people, voluntary activities and a greater knowledge of the field of youth, while respecting the areas of responsibility set out in the Treaties' (Resolution 2002). It is argued that subsidiarity is compatible with enhanced co-operation at European level, and that encouraging countries to work together in this way is likely to enhance the impact and coherence of national policies.
} 